\title{
Short Sea Shipping on the West Coast of Korea: Keys to Activating the Shipping Industry in Preparation for Korea Unification Era
}

Author(s): Sung-Woo Lee, Sung-Ho Shin, Hee-Sung Bae

Source: Journal of International Logistics and Trade 2020; 18(2):91-105

Published by: Jungseok Research Institute of International Logistics and Trade, Inha University

DOI: https://doi.org/10.24006/jilt.2020.18.2.091

The Journal of International Logistics and Trade is an official journal published by Jungseok Research Institute of International Logistics and Trade, Inha University, Korea. JILT welcomes manuscripts that advance the practice and science of logistics, trade, and other related fields.

Frequency: Quarterly (March, June, September, December)

Stable URL: https://www.ejilt.org

The Jungseok Research Institute of International Logistics and Trade is a specialized academic research institute representing Inha University and the Inha Foundation in Korea. The institute aims to become a representative institute in Northeast Asia in the research of logistics and trade.

Stable URL: https://jrieng.inha.ac.kr

(C) Copyright. Jungseok Research Institute of International Logistics and Trade.

This is an Open-Access article distributed under the terms of the Creative Commons Attribution NonCommercial License (http://creativecommons.org/licenses/by-nc/4.0/) which permits unrestricted noncommercial use, distribution, and reproduction in any medium, provided the original work is properly cited 


\title{
Short Sea Shipping on the West Coast of Korea: Keys to Activating the Shipping Industry in Preparation for Korea Unification Era
}

\author{
Sung-Woo Lee ${ }^{1}$, Sung-Ho Shin ${ }^{2,}{ }^{,}$, Hee-Sung Bae ${ }^{3}$ \\ ${ }^{1}$ General Policy Research Division, Korea Maritime Institute, Busan, Korea \\ ${ }^{2}$ Research Information Analysis Center, Korea University, Seoul, Korea \\ ${ }^{3}$ Department of International Trade, Kyonggi University, Suwon, Korea
}

Received $\quad$ May 19, 2020
Revised $\quad$ June 05, 2020
Accepted June 18, 2020

*Corresponding author: Sung-Ho Shin
Research Information Analysis Center,
Korea University, Seoul, Korea
Tel: +82-2-3290-1207
E-mail: sungho_shin@korea.ac.kr

\begin{abstract}
This study aims to analyze information on vessel traffic between the two Koreas with a probability distribution for each route/vessel type. The study will then conduct an estimate for maritime transport patterns of inter-Korean trade in the future. To analyze the flow of inter-Korean coastal shipping, this study conducted visualization analysis of shipping status between North and South Korea by year, ship type, and port using navigation data of three years from Port Logistics Information System (Port-MIS) sources during 2006 to 2008 , which saw the most active exchanges between the two governments. Also, this study analyzes shipping status between the two governments as a probability distribution for each port and provides the prospects for future maritime transport for inter-Korean trade by means of Bayesian Networks and simulation. The results of the analysis are as follows: i) when North-South routes are reopened, the import volume for sand from North Korea will be increased; ii) investment in the modernization of ports in North Korea is required so that shipping companies can generate profit through economies of scale; iii) the number of the operating vessels including container ships between the two governments is expected to increase like when the tensions and conflict on the Korean Peninsula was release, especially between Busan port in South Korea and Nampo port in North Korea; and iv) among container ships, transshipment containers imported and exported through Busan Port will be shipped to North Korea by feeder transportation.
\end{abstract}

Keywords Korea Unification Era, South-North Korea maritime co-operation, Shipping, Vessel traffic, Bayesian Networks, Simulation

\section{Introduction}

The global shipping industry, which is showing excessive overcapacity along with a decrease in trade volume due to the global economic slowdown, has been facing difficulties for many years. These difficulties are only getting worse in the aftermath of COVID-19. It is difficult to find a positive outlook for the global shipping industry in the near future, and the domestic shipping industry is facing difficulties as well. It is evaluated that Hanjin Shipping, the world's seventh largest container shipping company, has lost its competitiveness in domestic shipping industry (Shin et al. 2019).

As such, the shipping industry faces a difficult situation both internally and externally, but the degree to which the shipping industry contributes to the national economy is still large. The shipping industry is an important industry for countries wishing to achieve economic development through trade with foreign countries (Kim 2011), and the contribution of shipping and port is very high against the background of national and economic revitalization (Kim 1998).

In this situation, several experts view the increase in trade with North Korea as an opportunity for the domestic shipping industry to take off again. The coastal shipping between the North and the South has been more than fulfilling the basic task of cargo transportation, and actively utilizing the shipping infrastructure, which plays a large role in economic development, to utilize it for inter-Korean economic growth and trade with Eurasia. Considering the economies of scale when transporting cargo between the North and the South, maritime transport has the greatest advantage (Kim 1994a, 1994b), and accordingly the importance of maritime transport is set to increase (Im 1995). 


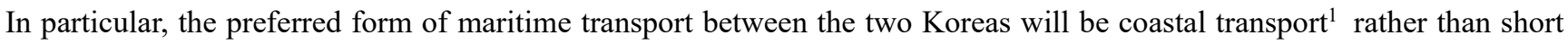
sea shipping, so the advent of the era of inter-Korean peace on the Korean Peninsula will lead to the development of the coastal transport industry. If economic cooperation between the two Koreas is active and the exchange increases, the volume of coastal transportation will increase, and at the same time, it will greatly contribute to the development of the domestic shipping industry. As the volume of trade with North Korea increases, ships operating only in South Korea will be responsible for transportation to North Korea. Therefore, the transportation distance (ton-mile) will increase greatly, creating a positive effect on the shipping industry, such as improving the profitability of shipping companies focused on coastal shipping. The increase in cargo volume between the North and the South will also strengthen the demand for coastal fleets (Kim 1994b), providing an opportunity to invigorate coastal transportation and development of the domestic shipping industry.

The coastal transportation industry will not only benefit from increased trade between the two Koreas, but will also play an important role in promoting inter-Korean economic cooperation and opening of North Korea ( $I m$ 1995). South-North Economic Cooperation precedes and serves as the very foundation for the unification of the two Koreas, and this economic cooperation will also lead to the exchange of human and material resources. This is because inter-Korean shipping will serve as a means to the vitalization of exchanges with the support of economic cooperation between the two Koreas by actively promoting such exchanges (Hwang and Chun 2018). Shipping also plays a role in providing the basic framework for material exchange and economic cooperation (Park and Lee 2017), and maritime transportation between the North and South is a mode of 'maintaining the system' in North Korea, that is more welcome to North Korea compared to overland or rail transportation. Shipping is the preferred transportation mode for North Korea over other mode (i.e., truck, train, and aviation) because shipping can minimize the contact between residents of two Koreas at the private-level (Kim 1998).

As such, inter-Korean coastal transportation plays a role in promoting economic cooperation between the two Koreas, and at the same time, the trade volume is bound to increase driven by greater economic cooperation between the two Koreas. Therefore, assuming that the Korean Peninsula will be increasingly peaceful in the future and trade between the two Koreas will increase, preparations and inspections of coastal transportation between the two Koreas should be made from various perspectives.

This study intends to suggest the role of Korean shipping and an appropriate policy in the future period of peace on the Korean Peninsula through an analysis of sea transportation between the North and the South by estimating the vessel traffic pattern. To do this, the previous studies related to the inter-Korean shipping / ports were identified in Chapter 2. Chapter 3 briefly examined the characteristics of maritime transportation between North and South Korea and the North Korean ports located on the West coast. Chapter 4 describes the methodology (Bayesian Networks). In Chapter 5, Port-MIS data on entry and departure of ships that traveled to and from the North and South Ports over the past three years, which had the highest volume of inter-Korean traffic in recent times, was collected and analyzed. Also, the Bayesian Networks (BN) was used to implement the status of vessels traffic by route and port. In Chapter 6, based on distribution of vessels traffic, a scenario-byscenario analysis was conducted on how North-South coastal transportation would change when North Korea develops a hinterland. Chapter 7 presents the conclusions.

\section{Literature Review}

\subsection{Studies on shipping ports of North and South Korea}

The shipping industry has an important role in preparing for the era of peace on the Korean Peninsula, as the advancement of shipping cooperation between the two Koreas can promote the opening of North Korea (Kim 1998). At the same time, the era of peace on the Korean Peninsula will be a growth engine for both Koreas, given that active economic exchanges between the two Koreas will increase cargo volume through the sea for both sides. For these reasons, sectoral studies related to interKorean shipping ports have been conducted steadily (Table 1).

\footnotetext{
${ }^{1}$ 'Short Sea Shipping' began to emerge in Europe from the 1900s, and unlike traditional coastal shipping, it is a concept that closely links the modes of transportation by land, sea, and air. Through this, it means a shipping-oriented complex transportation system that creates high added value in the logistics sector. It means efficient and eco-friendly integrated logistics or such transportation system (Seo et al. 2012). Considering the situation in which North Korea's shipping / port infrastructure is poor in the current situation as inter-Korean maritime transport is suspended, it is more appropriate to apply the concept of 'Coastal Shipping' rather than 'Short Sea Shipping'. Therefore, in this study, the expression 'coastal transportation' was used instead of the word 'Short Sea Shipping'.
} 
Table 1. Research topics and subjects related to Inter-Korean shipping / ports

\begin{tabular}{|c|c|c|}
\hline Author(s) (year) & Research topics and subjects & Methodology \\
\hline \multicolumn{3}{|l|}{ [1] Port perspective } \\
\hline Lee (2018) & Port Development Plan of North Korea & Status analysis on ports \\
\hline Lee et al. (2018) & $\begin{array}{l}\text { Finding possible cooperation projects in the port logistics } \\
\text { field and suggesting a promotion plan }\end{array}$ & $\begin{array}{l}\text { Analytic hierarchy process, } \\
\text { status analysis \& policy proposal }\end{array}$ \\
\hline Park \& Park (2019) & Evaluation of port selection factors & Analytic hierarchy process \\
\hline \multicolumn{3}{|l|}{ [2] Shipping perspective } \\
\hline $\operatorname{Kim}(1994 a, 1994 b)$ & Strengthening coastal shipping functions & Status analysis \& policy proposal \\
\hline $\operatorname{Im}(1995)$ & Proposals for inter-Korean shipping cooperation & Status analysis \& policy proposal \\
\hline Jung (2008) & $\begin{array}{l}\text { Presenting the direction of development for inter-Korean } \\
\text { shipping }\end{array}$ & Status analysis \& policy proposal \\
\hline \multicolumn{3}{|c|}{ [3] Port and shipping perspective } \\
\hline $\operatorname{Kim}(2002)$ & $\begin{array}{l}\text { North Korea Port Development Plan and North-South Port } \\
\text { Cooperation }\end{array}$ & Status analysis \& policy proposal \\
\hline $\operatorname{Kim}(2011)$ & The challenges faced by the North Korean shipping industry & Status analysis \& policy proposal \\
\hline Hwang \& Chun (2018) & Proposal for inter-Korean shipping cooperation & Status analysis \& policy proposal \\
\hline \multicolumn{3}{|l|}{ [4] Other perspective } \\
\hline Koo (2019) & Joint development for fisheries, shipping, and offshore & Status analysis \& policy proposal \\
\hline
\end{tabular}

Previous studies on port cooperation between North and South Koreas include research by Lee (2018), Lee et al. (2018), and Park and Park (2019). Lee (2018) investigates the status of North Korea's economy, trade, and port logistics, and suggests directions for developing port logistics facilities in North Korea. In particular, the current status of port facilities and maritime trade in North Korea and the trend of changes in maritime traffic volume in North and South Koreas were examined, and the problems port logistics facilities face at the present time were analyzed. In addition, the study suggested that each development direction for individual ports in North Korea should be considered in the development of North Korean ports by dividing them into short-term and long-term. Lee et al. (2018) analyzed the contents and performance of North-South cooperation projects that were carried out in the port logistics sector and analyzed the status of port logistics in North Korea. In addition, a new project for promoting port logistics between the two Koreas was derived according to the government's policy, and the Analytical Hierarchy Process (AHP) was utilized to propose a plan for selecting and implementing key projects in the port logistics sector between the two Koreas. Park and Park (2019) conducted a study to determine the requirements that should be considered for the efficient development of ports located on the North Korean West Coast. This study, using the questionnaire and the hierarchical analysis method, argued that the development of shipping and port infrastructure should take precedence in the development of North Korean ports. In addition, the authors suggested that a governance system should be established to operate and manage the ports during North Korea's port development.

The major literature on cooperation and development in the North and South Korean shipping sector includes the research of Jung (2008), Im (1995), and Kim (1994a, 1994b). Kim (1994a, 1994b) highlights the importance of comparing inter-Korean shipping capabilities. The author emphasized that strengthening of coastal shipping functions will play a critical role in interKorean shipping cooperation in the unified Korean era. This study also argues that South Korea should drive and provide leadership for the North's shipping industry. Im (1995) presents the necessity of cooperation in the shipping sector and provides justifications for establishing an inter-Korean route, with the view that maritime cargo transportation between the two Koreas plays an important role in the realization of economic cooperation. This study examines the problems of inter-Korean shipping cooperation and suggests solutions to each issue in order to present a plan for promoting inter-Korean shipping cooperation. In addition, it argues that inter-Korean shipping cooperation brings mutual benefits and prosperity for the two Koreas and is an essential part of becoming a logistics hub in Northeast Asia in the 21 st century. The authors also argue that an agreement between the two Koreas is a prerequisite to such cooperation, and that such agreements can reduce various issues that may arise during inter-Korean trade and sea transportation. Jung (2008) analyzed the status of inter-Korean shipping and associated problems. Through this analysis, the author suggested measures for the development of shipping between the two sides.

Meanwhile, shipping and ports are deeply related industries, and studies have been conducted to analyze North Korean shipping and ports at the same time. Kim (2002) presented the status of North Korean ports and the current status of interKorean maritime trade. Further, the author proposed measures for exchange and cooperation between the two Koreas from the 
viewpoint of shipping and ports. In particular, the study argues that development of North Korea's ports is a necessary condition for the Korean Peninsula to grow as a logistics hub in Northeast Asia, from the viewpoint of the geopolitical position of the Korean Peninsula. In addition, the study proposes a plan for cooperation between the two Koreas for inter-Korean port exchange, a plan to promote mid- and long-term port development, and a way to recover investment costs. Kim (2011) analyzes the current state of the North Korean shipping industry from the perspectives of ports, shipping, and shipbuilding. Also, the author discusses the challenges and improvement plans for each sector. The study suggests that improvement of the North Korean port facilities, port administration and operation and the poor transportation system are crucial to invigorating the shipping industry in North Korea. Hwang and Chun (2018) compared the current state of North Korea's shipping and ports with that of South Korea, analyzed the problems expected when resuming maritime transport between North and South Korea, and cited specific measures for inter-Korean shipping cooperation. Koo (2019), meanwhile, proposed a plan for maritime cooperation between the two Koreas in terms of fisheries, shipping, and marine oil fields, emphasizing that new measures should be created between the two Koreas by solving various challenges facing the North's shipping and port industries (deterioration of ports, customs issues, and so on.) and improving inter-Korean relations.

Previous studies on inter-Korean shipping and port cooperation carried out in-depth analysis of North Korea's port and shipping status, as well as the current problems faced in the efforts to achieve peace on the Korean Peninsula. It is an important resource that presents practical suggestions. However, because data on shipping transport between the North and the South is limited, data-based research that can serve as the basis for various policies suggested in previous studies is relatively insufficient. However, Ducruet (2008) investigated the distribution of direct sea transportation connections among ports and the evolution of traffic in North Korea by country and also analyzed the main commodities between 1985 to 2006 with Lloyd's Marine Intelligence Unit (LMIU) data. Ducruet et al. (2009) also examined the concentrations of container traffic (1985-2006) and vessel traffic (1985-1991) at North Korean ports using the LMIU data. However, the studies performed by Ducruet (2008) and Ducruet et al. (2009) did not analyze by product (vessel type) transportation between each inter-Korean port.

In order to fill these gaps in the literature, this paper aimed to model vessel traffic and perform simulations using data from the port logistics information database, assuming the era of unification of the Korean Peninsula.

\subsection{Studies of methodology: Bayesian Networks (BN)}

$\mathrm{BN}$ has been proven to be a powerful approach to enabling inferences as well as expressing uncertain knowledge. This analytic approach can be used for scenario analysis and probability prediction, and has been widely applied in a range of real applications including diagnosing defects and decision making within a complex system (Jiang et al. 2020; Wan et al. 2019). Also, $\mathrm{BN}$ is the preferred methodology due to the advantage that allows modeling of dependencies between influential factors (Baksh et al. 2018).

For these reasons, $\mathrm{BN}$ has been used in the maritime field with forward (or predictive) and backward (diagnostic) analysis (Jiang et al. 2020) in areas including maritime accidents (Akhtar and Utne 2014; Jiang et al. 2020; Wang and Yang 2018), maritime risk/safety (Trucco et al. 2008; Yang et al. 2019), maritime supply chain risks (Wan et al. 2019), port state control inspection (Yang et al. 2018a; Yang et al. 2018b), predicting a containership's arrival punctuality (Salleh et al. 2017), analysing tanker shipping bankruptcy risks (Wang et al. 2017), research on improving the resilience of a seaport system (John et al. 2016), analysing slow steaming (Abdul Rahman et al. 2015; Rahman et al. 2012), container port safety evaluation (Alyami et al. 2014), assessing the operational reliability (Salleh et al. 2014), and estimation of navigational risks (Zhang et al. 2013).

Within the BN-based approach, the general BN approach has been applied in the maritime domain (Akhtar and Utne 2014; Jiang et al. 2020; Wang et al. 2017; Wan et al. 2019). Furthermore, advanced methods have been introduced to investigate the effectiveness and potential between influential factors such as hybrid ER (Evidential Reasoning)-BN model (Yang et al. 2019). Further, a strategic game model is formulated by incorporating the BN model outcomes (Yang et al. 2018a), fuzzy rule-based BN (Abdul Rahman et al. 2015; Alyami et al. 2014; John et al. 2016; Rahman et al. 2012; Salleh et al. 2014, 2017; Wan et al. 2019) incorporation model of formal safety assessment and BN (Trucco et al. 2008; Zhang et al. 2013).

Based on literature, although BN was applied in various ways, it is noteworthy that no Bayesian probability model has been developed for analyzing the flows of container vessels and cargo considering modal shift; thus, making these attempts is essential for the current study. This data-driven approach can reduce the reliance on specialists, as well as bring down the time required to apply the knowledge gained from experts to build BN. In some cases, the accuracy of the model can be increased (Yang et al. 2018a). Thus, this study incorporated a data-driven approach in the shipping between two Koreas to develop the concept of a new logistics system in South Korea. 


\section{Status of Shipping and Ports in North Korea}

\subsection{Status of shipping between the two Koreas}

The volume of sea transport and the number of vessels between the two Koreas have increased significantly since 2005 as shown in Table 2. The increase in trade volume is due to the active exchange between the two Koreas based on the 'NorthSouth Shipping Agreement' (August 2005). However, after a tourist was shot by North Korean soldiers in July 2008, tours to Mount Kumgang were suspended. Furthermore, inter-Korean economic cooperation was halted altogether as inter-Korean relations deteriorated following the North's nuclear test and the 2010 attack on the ROKS Cheonan warship. Since then, operation of the national flag vessels has been completely banned, and little maritime traffic has been recorded between the two Koreas to date.

\subsection{Major ports of North Korea' in the Yellow Sea (West Coast)}

The representative ports located on the west coast of North Korea are Nampo Port, Songlim Port, and Haeju Port which is called the gateway port of Pyongyang (Hwang and Chun 2018; Lee 2018). Ports located on the west coast of North Korea have a significant disadvantage in terms of the difference between tides, but a large number of North Korea's economic development zones are situated on the West Coast (Park and Park 2019). Additionally, the West Coast region has a geographical advantage in that it is adjacent to the major ports of China, and furthermore the coastal areas are adjacent to a large concentration of the working population. The social infrastructure of the West Coast region is also relatively better than the East region (Park and Park 2019). Also, even among Korea's ports, the ports of Incheon and Pyeongtaek, which are closest to the metropolitan area, are located on the west coast, so maritime transport between the two Koreas has the potential to be active along the West Coast.

The characteristics of the three ports (Nampo Port, Haeju Port, and Sinuiju Port) on the West Coast of North Korea, which are the subjects of this study, are as follows. Being adjacent to Pyongyang, Nampo Port serves as the main gateway to Pyongyang's special economic zone and plays an import role in the export of raw materials / finished products in connection with major industrial complexes. Nampo Port also plays a key role in economic cooperation between the two Koreas as well as trade with China (Park and Park 2019). The Pyongyang Industrial District is located behind Nampo Port, bringing in raw materials and taking out finished products from related industries. For these reasons, modernization and expansion of the container port are top priorities (Lee et al. 2018).

Haeju Port is also located near Pyongyang and adjacent to the Gaeseong Industrial Complex and Haeju Special Economic Zone. Above all, Haeju Port has facilities to transport sand, a large amount of aggregate resources (Park and Park 2019). Also, Haeju Port is capable of docking 10,000 tons of tankers as ports for importing petroleum products, and has the capacity to produce petrochemical combinats. This port serves as a gateway for export to various mineral resources departments and has

Table 2. Status of sea transportation volume and the number of vessels operating between North and South Korea

\begin{tabular}{|c|c|c|c|c|c|c|c|c|c|}
\hline \multirow[b]{2}{*}{ Year } & \multicolumn{3}{|c|}{ Volume of sea transportation $(1,000$ tons $)$} & \multirow[b]{2}{*}{$\begin{array}{c}\text { No. of } \\
\text { vessel } \\
\text { operation }\end{array}$} & \multirow[b]{2}{*}{ Year } & \multicolumn{3}{|c|}{ Volume of sea transportation ( 1,000 tons $)$} & \multirow[b]{2}{*}{$\begin{array}{c}\text { No. of } \\
\text { vessel } \\
\text { operation }\end{array}$} \\
\hline & Total & $\begin{array}{c}\text { South Korea } \\
\rightarrow \\
\text { North Korea }\end{array}$ & $\begin{array}{c}\text { North Korea } \\
\stackrel{\rightarrow}{\text { South Korea }}\end{array}$ & & & Total & $\begin{array}{c}\text { South Korea } \\
\rightarrow \\
\text { North Korea }\end{array}$ & $\begin{array}{l}\text { North Korea } \\
\stackrel{\rightarrow}{\text { South Korea }}\end{array}$ & \\
\hline 1996 & 335 & 148 & 187 & 322 & 2008 & 15,060 & 144 & 14,916 & 7,435 \\
\hline 1997 & 611 & 361 & 250 & 357 & 2009 & 1,909 & 1,844 & 65 & 2,577 \\
\hline 1998 & 558 & 396 & 162 & 602 & 2010 & 1,068 & 34 & 1,034 & 1,432 \\
\hline 1999 & 984 & 781 & 203 & 1,714 & 2011 & 2 & 2 & 0 & 142 \\
\hline 2000 & 703 & 547 & 156 & 2,073 & 2012 & 1 & 1 & 0 & 228 \\
\hline 2001 & 641 & 402 & 239 & 1,686 & 2013 & 1 & 0 & 1 & 16 \\
\hline 2002 & 1,056 & 899 & 157 & 1,823 & 2014 & 41 & 0 & 41 & 1 \\
\hline 2003 & 1,048 & 841 & 207 & 2,022 & 2015 & 255 & 0 & 255 & 10 \\
\hline 2004 & 1,108 & 625 & 483 & 2,124 & 2016 & 0 & 0 & 0 & 0 \\
\hline 2005 & 6,795 & 947 & 5,848 & 4,497 & 2017 & 0 & 0 & 0 & 0 \\
\hline 2006 & 16,306 & 885 & 15,421 & 8,401 & 2018 & 0 & 0 & 0 & 2 \\
\hline 2007 & 25,111 & 1,347 & 23,764 & 11,891 & & & & & \\
\hline
\end{tabular}

Source: Statistics Korea (2020). 
been a port dedicated to cement since 1973. Metal industrial complexes and smelters are located in the hinterland, but it is analyzed that due to the deterioration of ports, it is necessary to pursue the modernization of berths for general cargo (Lee et al. 2018).

Sinuiju Port also has a hinterland (Hwanggumpyong and Wihwa-Do Economic Zone and Sinuiju International Economic Zone) (Lee et al. 2018), but its functions as a port have hardly been fulfilled due to a lack of facilities to cope with sedimentation and tides (Hwang and Chun 2018).

\section{Methodology}

This study investigates the probability of vessel traffic by sea transportation route between the two Korea's ports based on data on the number of vessels calling at North and South Koreas' ports over three years. With the probability distribution for vessel traffic similar to the past, BN enables scenario-by-scenario (based on the assumption that sea transport between North and South is resumed) estimation of vessels between seaports in North and South Korea.

The BN approach is an analytical method for probabilistic analysis based on Bayes' Theorem and networking techniques (Wan et al. 2019). The BN model uses graphical presentation (Directed Acyclic Graph, DAG) that consists of a set of nodes and arcs, combined with mathematical inference calculation (John et al. 2016). This graphical presentation of probability represents the structure of causal dependence between nodes and the probabilistic causal dependence among the variables (Salleh et al. 2014; Trucco et al. 2008; Wang et al. 2017). This methodology is also classified as an artificial intelligence tool as it aims to provide a framework to support decision-making for problems involving probabilistic reasoning under uncertainty and complexity (Nadkarni and Shenoy 2001; Salleh et al. 2014). The Bayes' Theorem on which the BN is based can be formulated as follow (Akhtar and Utne 2014):

$$
P(Y \mid X)=\frac{P(X \mid Y) P(Y)}{P(X)}
$$

This theorem connects the networks using $\mathrm{X}$ and $\mathrm{Y}$, indicating that $\mathrm{X}$ has a direct causal effect on $\mathrm{Y} . P(Y \mid X)$ is the posterior probability of the hypothesis and $P(X \mid Y)$ is the conditional probability indicating the probability that event $X$ occurs given the condition that the event $Y$ occurs. $P(Y)$ is the prior probability of the hypothesis (Akhtar and Utne 2014; Wang and Yang 2018).

$$
P\left(Y \mid X_{1}, X_{2}, \ldots, X_{n}\right)=\frac{P\left(X_{1}, X_{2}, \ldots, X_{n} \mid Y\right) P(Y)}{P\left(X_{1}, X_{2}, \ldots, X_{n}\right)}
$$

Algorithms based on the Bayes' Rule and Chain Rule indicate that a "BN is a representation of the joint distribution over all the variables represented in the DAG and the marginal and conditional probabilities can be computed for each node of the networks" (Trucco et al. 2008).

Thus, this study developed a model based on the BN to investigate the possibility of coastal shipping considering the development of North Korea's hinterlands that affect the volume of sea transport between the two Koreas as well as coastal shipping operations in Korean waters.

\section{Dataset and Preparing for the Bayesian Networks Analysis}

\subsection{Data collection and pre-processing}

The data for analysis was collected from the "Status Data on Ships Entering and Leaving" in the Port Management Information System (Port-MIS ${ }^{2}$ ). This data contains information on the time of vessels' entry and departure (year, month, date, and exact time), previous calling ports, next port of call, types of vessels, as well as gross tonnage and flag of the country. The data from the 2000s to the recent year (2019) was intended to be used for analysis, but the time range of inter-Korean transport ships was limited to three years (2006-2008). This is because in the 2000s, three years (2006-2008) constituted the period

${ }^{2} \mathrm{https}: / /$ new.portmis.go.kr 
when the largest amount of maritime cargo was traded between the two Koreas. As relationship between the two Koreas deteriorated, since there has been little maritime transportation between the two sides, and hence data for subsequent years has not been used for analysis.

Using the Port-MIS database, data on vessels with records of exchanges with North Korean Ports were extracted through filtering (based on Korean port entry records). In addition, even if it is set as a 'vessel entering South and North Korea' in the voyage classification, cases where either origin port or destination port is overseas (mainly China) were excluded. Based on these criteria, assuming that the transportation of cargo through inter-Korean vessels is resumed, it is possible to assume the cargo transportation status of future vessels by route/ship between the North and South ports utilizing transportation records for the most active three-year period.

Based on the collected data, the status (based on the number of operation) of South and North Korean ports in the three years (2006-2008), where navigation between the two Koreas was most active, is shown in Figure 1. The thickness of the line indicates the quantity of vessel traffic: the thicker the connection line between the ports, the greater was the number of operations between the two ports. Figure 1(a) indicates that the most frequent route was the Incheon-Haeju route located on the West Coast.

In the same period, if the number of times of maritime transport between North and South Koreas is multiplied by the total tonnage of each vessel operating each route, the connection lines between the ports are displayed as shown in Figure 1(b). This is similar to the 'tonne-mile' concept, and is intended to prevent distorted understanding with respect to the importance of the route when expressed only by the number of operations. Based on this concept, not only the number of times of operation of the vessel but also the size of the ship (tonnage) multiplied by the operation of each vessel is finally summed up and displayed for each route. These do not provide accurate values, but since the exact value of the cargo transported by port/route/vessel type is unknown due to the lack of data, this method provides an overview of the volume of cargo transported on each route and

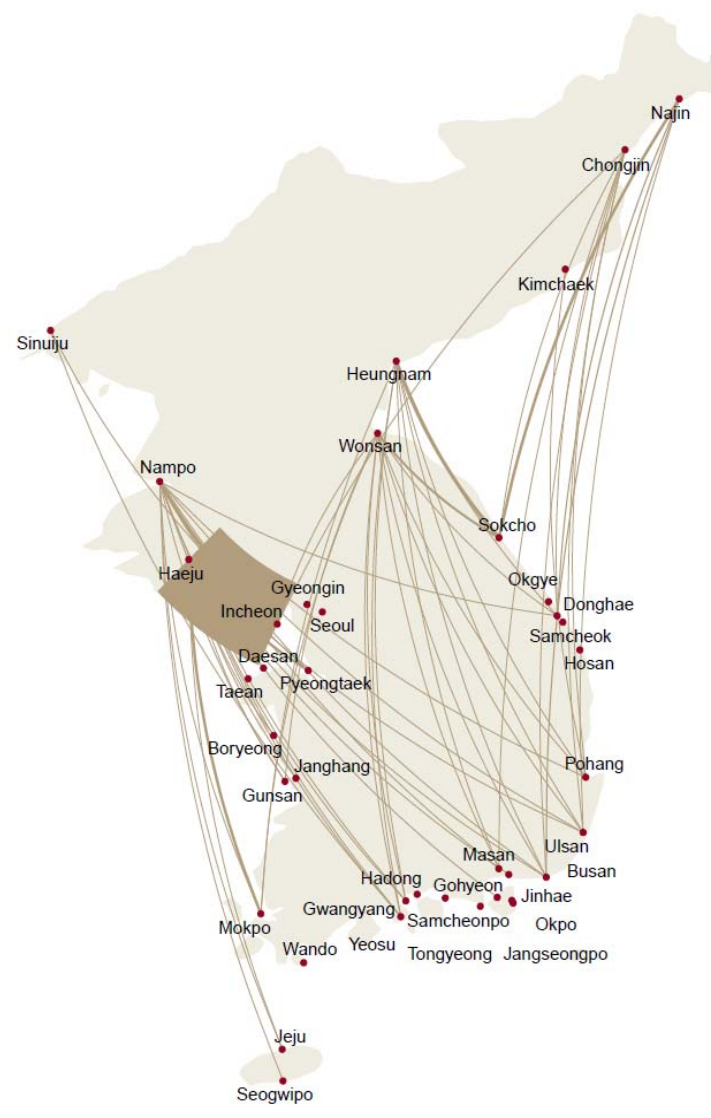

(a) Number of vessel operation

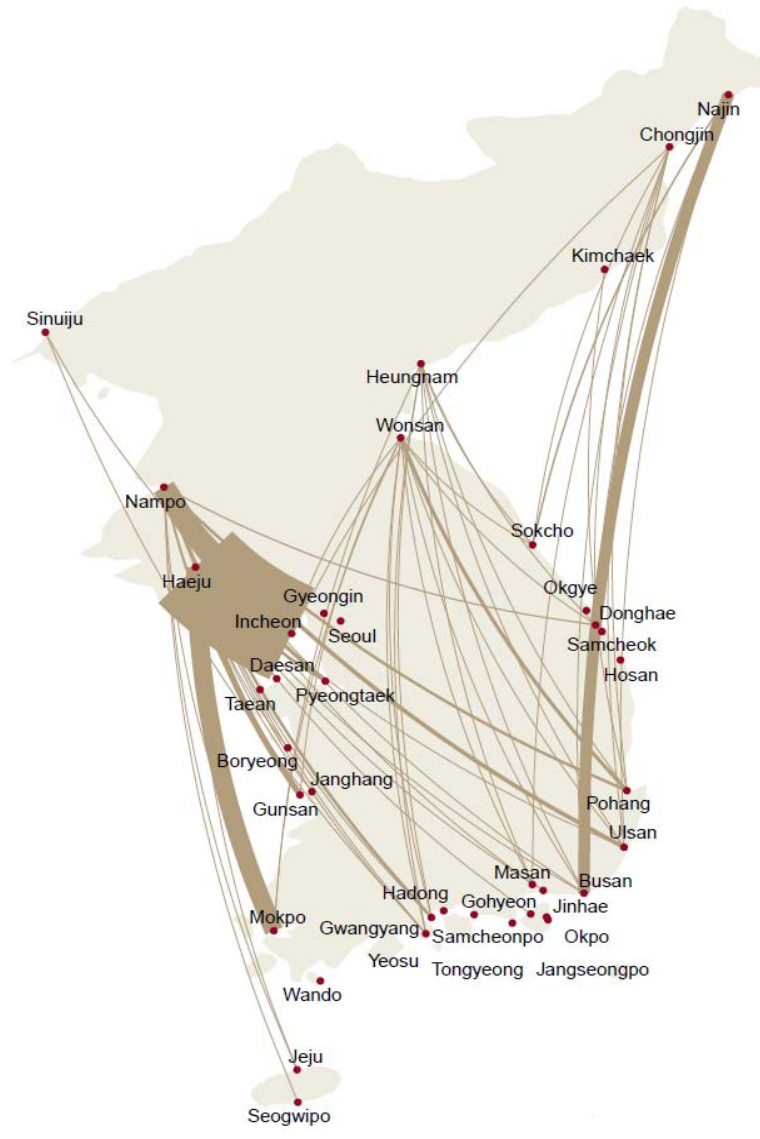

(b) Number of vessel operation $\times$ gross tonnage (of each vessel)

Figure 1. Status of maritime transportation between North and South Korea (2006-2008).

Note: Ulleungdo and Dokdo were excluded for convenience. 
shows it in relative size, allowing comparison by route.

For example, in Figure 1(a), the frequency of vessel traffic between Haeju Port and Incheon Port seems to indicate this as a relatively important route, but considering that the main transport item between Haeju Port-Incheon Port is sand moved by barge ships $^{3}$ of an average tonnage of 250 tons, it is clear that small ships operate between the two ports at a high frequency. On the other hand, in the case of container ships operating between Najin Port-Busan Port, vessels with an average of 2,000 tons are in operation, so the size of the vessel also needs to be considered. Looking at Figure 1(b) from this point of view, the approximate transportation volume of cargo on the inter-Korea sea route along the West Coast (the value obtained by multiplying the gross tonnage [of each vessel] by the number of trips for each route) is high not only on the Heaju Port-Incheon Port route but also Nampo Port-Incheon Port and Haeju Port-Mokpo Port routes.

Through this visualization, it was possible to understand the status of sea trade between the two Koreas in the past and to analyze the patterns of routes between the two Koreas by port/by cargo (by vessel type). However, this visualization-based analysis presents limitations in simultaneously viewing two or more variables. In other words, although it can be examined using the port-by-vessel type mode, it is difficult to consider the current status of each port-by-vessel type at the same time using parameters such as year and ship size. This study, thus, intends to conduct an analysis using BN as a way to overcome these limitations.

\subsection{Conditional Probability Tables (CPT) for Bayesian Networks}

Depending on the year, gross tonnage, vessel type, and the port of South Korea (domestic port), the following connections (Figure 2) were established to analyze the distribution of the routes to North Korean ports (i.e., which ports are used in North Korea).

A BN that relies on Bayes' theorem can be presented with a directed acyclic graph connected with each node. The arrows connect nodes indicating that they influence each other. Further, the direction of the arrows indicates the conditional dependent relationship of each node (Zhang et al. 2013) and represents the propagate information between nodes. Through the Netica software, the BN concept model of coastal shipping in Korea is presented in Figure 2. The distribution of 'Gross Tonnage' and 'Vessel Type' can be assumed to be affected by 'year' because these two nodes are presented differently according to the 'Year'. The distribution of ports in South Korea ('Domestic Port') is influenced by 'Gross Tonnage', 'Year', and 'Vessel Type' that operated North and South Korea ports. Lastly, the distribution of North Korean ports ('NK (North Korea) Port') varies depending on the South Korean port ('Domestic Port') and the type of ship ('Vessel Type') as shown in Figure 2.

Data collected from Port-MIS is applied to the BN utilizing Excel's pivot function. Each node is entered in the form of Conditional Probability Tables (CPT), and the sum of each row should be $100 \%$ (enter the probability value of the combination). Table 3 shows the conditional probability table based on the number of vessel movements between the North and South ports.

\section{Results}

\subsection{Transport model between North and South Korea ports using Bayesian Networks}

Figure 3 shows the distribution of sea transport between North and South Korean ports (based on the number of vessel operations) by vessel type that applied CPT to the BN. The three-year maritime transportation trade between South Korea and North Korea has the highest distribution for Incheon and Haeju ports, and it can be seen that vessels with less than 500 tons account for $97.3 \%$ of all vessels. Barge and sand carriers carrying sand occupy a high proportion, and the number of reefer

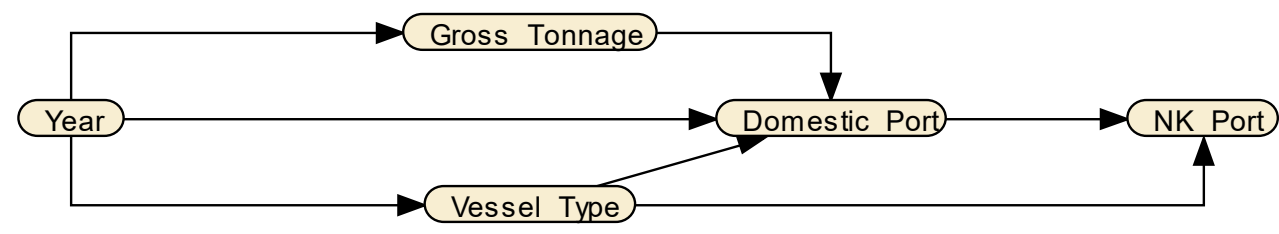

Figure 2. Connection by node in Bayesian Networks.

\footnotetext{
${ }^{3}$ In sea transportation with North Korea, barges mostly carry sand.
} 
Table 3. CPT based on the number of vessel movements between ports

\begin{tabular}{|c|c|c|c|c|c|c|c|c|c|}
\hline \multirow[b]{3}{*}{ Ports (South Korea) } & \multicolumn{9}{|c|}{ Ports (North Korea) } \\
\hline & \multicolumn{3}{|c|}{ West coast } & \multicolumn{5}{|c|}{ East coast } & \multirow{2}{*}{ Total } \\
\hline & Sinuiju & Nampo & Haeju & Wonsan & Heungnam & Kimchaek & Chongjin & Najin & \\
\hline Incheon & 0.5 & 3.6 & 95.7 & 0 & 0 & 0 & 0.2 & 0 & 100.0 \\
\hline Pyeongtaek & 0 & 8.6 & 91.4 & 0 & 0 & 0 & 0 & 0 & 100.0 \\
\hline Daesan & 0 & 100 & 0 & 0 & 0 & 0 & 0 & 0 & 100.0 \\
\hline Boryeong & 0 & 0 & 100 & 0 & 0 & 0 & 0 & 0 & 100.0 \\
\hline Janghang & 0 & 0 & 100 & 0 & 0 & 0 & 0 & 0 & 100.0 \\
\hline Gunsan & 0 & 10.2 & 89.5 & 0.3 & 0 & 0 & 0 & 0 & 100.0 \\
\hline Mokpo & 0 & 1.3 & 98.2 & 0.2 & 0.3 & 0 & 0 & 0 & 100.0 \\
\hline Gwangyang & 0 & 50.8 & 34.4 & 6.6 & 8.2 & 0 & 0 & 0 & 100.0 \\
\hline Yeosu & 3 & 27.3 & 63.7 & 3 & 3 & 0 & 0 & 0 & 100.0 \\
\hline Gohyeon & 0 & 0 & 100 & 0 & 0 & 0 & 0 & 0 & 100.0 \\
\hline Masan & 0 & 25 & 0 & 37.5 & 25 & 0 & 12.5 & 0 & 100.0 \\
\hline Jinhae & 0 & 0 & 100 & 0 & 0 & 0 & 0 & 0 & 100.0 \\
\hline Busan & 0 & 2.3 & 3.8 & 2.9 & 1.8 & 0 & 4.3 & 84.9 & 100.0 \\
\hline Ulsan & 0 & 56.6 & 10.4 & 11.3 & 6.6 & 0 & 10.4 & 4.7 & 100.0 \\
\hline Pohang & 0 & 21.3 & 0 & 74 & 1.2 & 0.8 & 2.7 & 0 & 100.0 \\
\hline Donghae & 0 & 3.4 & 0 & 11.4 & 19.4 & 0 & 6.8 & 59 & 100.0 \\
\hline Sokcho & 0 & 0 & 0 & 25.1 & 37.7 & 0 & 6.5 & 30.7 & 100.0 \\
\hline Jeju & 0 & 55.2 & 44.8 & 0 & 0 & 0 & 0 & 0 & 100.0 \\
\hline Seogwipo & 0 & 100 & 0 & 0 & 0 & 0 & 0 & 0 & 100.0 \\
\hline
\end{tabular}

Note: CPT, conditional probability tables.

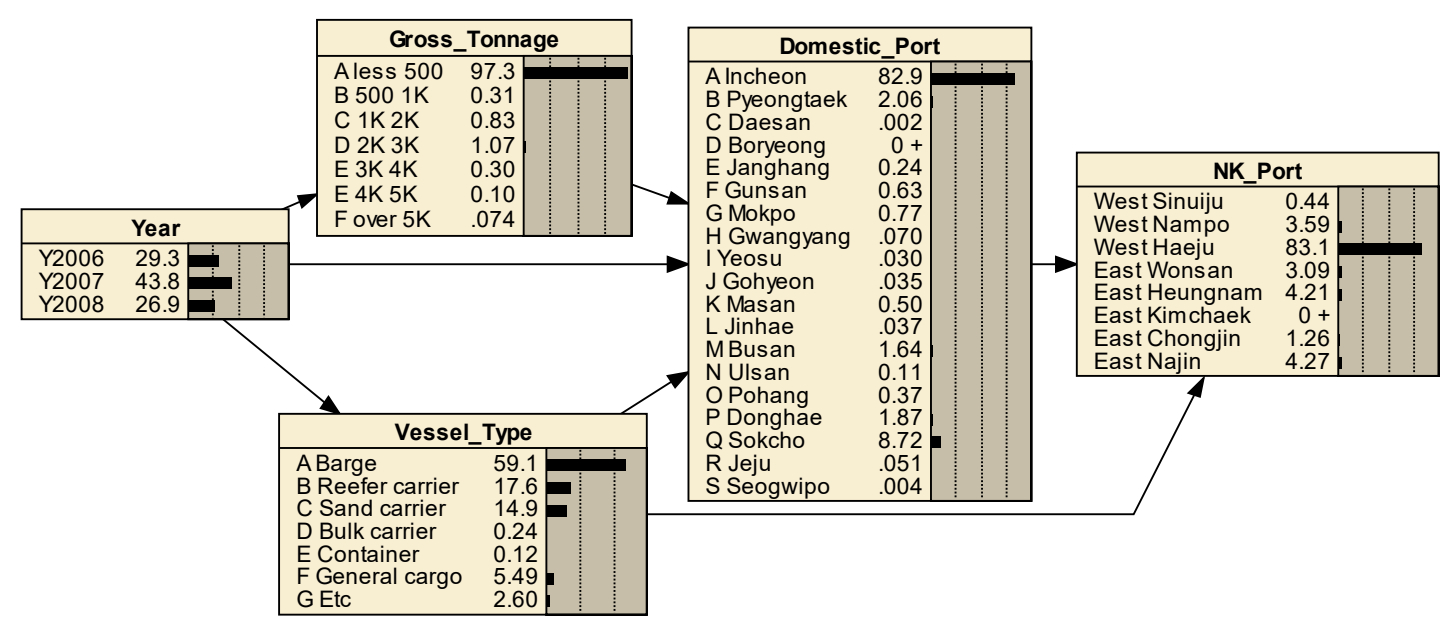

Figure 3. South-North Korea port route model.

carrier operations is also high (17.6\%). The number of vessels operated between the two Koreas in 2007 (43.8\%) was the highest among the three years.

\subsection{Transport model by port (located on the West Coast of North Korea)}

In the case of Sinuiju Port, vessel traffic to Incheon Port account for 99.9 percent, and the type of ships deployed can be identified as reefer carrier with less than 500 tons (Figure 4(a)). In the case of Nampo port, there was more vessel traffic with 


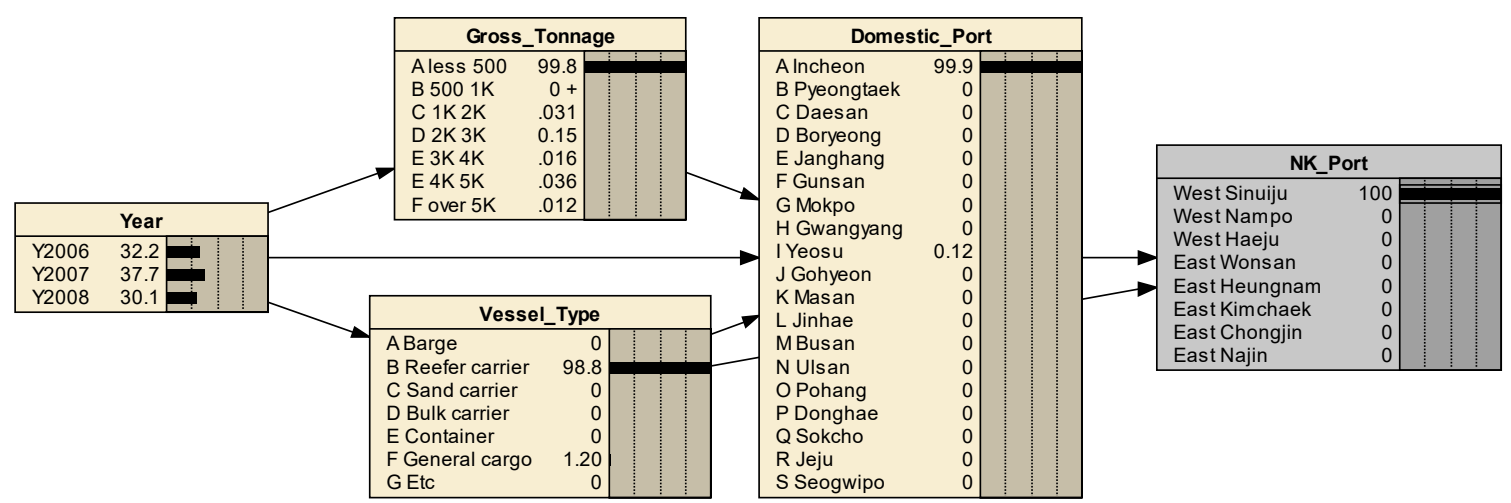

(a) Sinuiju port

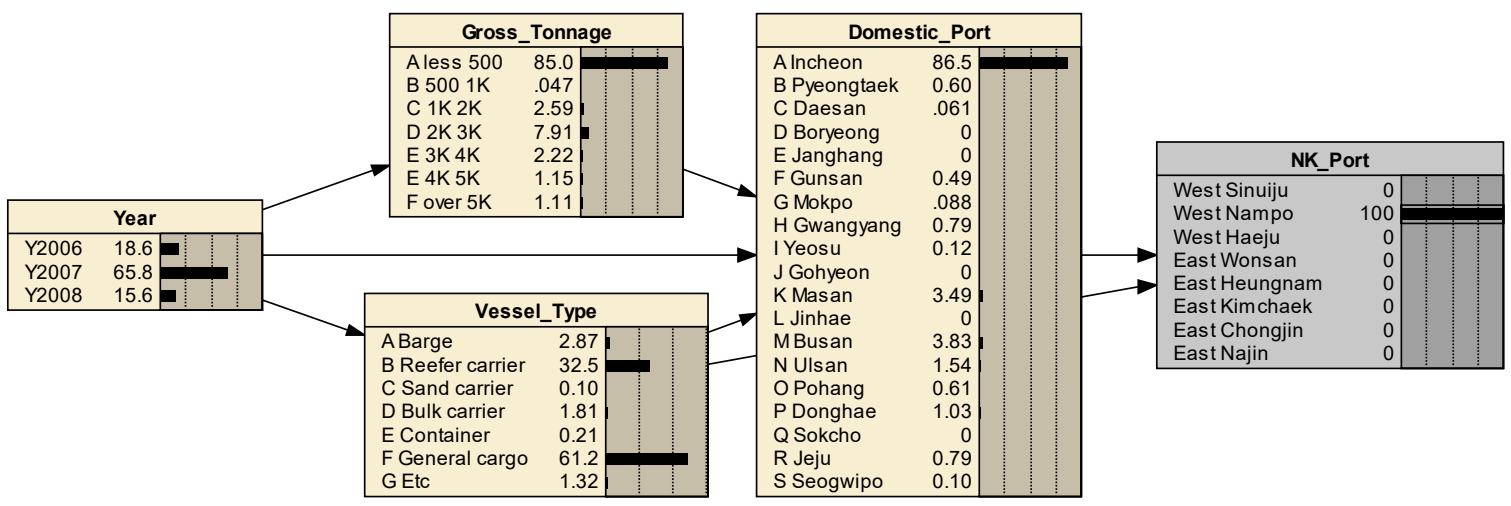

(b) Nampo port

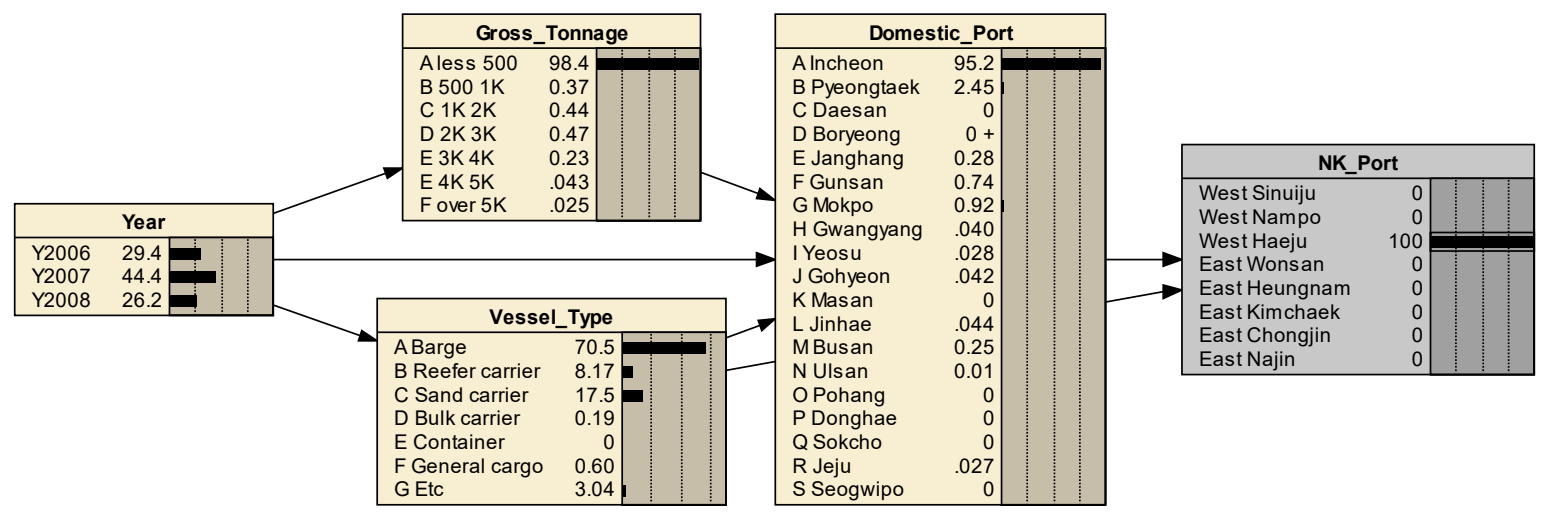

(c)Haeju port

Figure 4. Transport model by port (located on the West Coast of North Korea).

ports in South Korea compared to Sinuiju port, but the distribution for vessel traffic to Incheon port was the highest (86.5\%). Also, the distribution of general cargo and reefer carrier was high. Vessels with less than 500 tonnage were used frequently to operate between ports in North and South Korea, but the traffic patterns of vessels above 1,000 tons, accounting for about 15 percent, is injected. Lastly, vessel traffic from Nampo to Korean port was high in 2007 as shown in Figure 4(b). In the case of Haeju Port, the number of vessels operated with Incheon Port was the highest, and most vessels were less than the 500 tonlevel in size, which are used for transporting sand transported by barge and sand carrier (Figure 4(c)).

\subsection{Simulation}

This study conducted a simulation of how the maritime trade between the two Koreas will change if exchanges between the 
two Koreas are resumed through coastal transportation. To do this, it is assumed that economic cooperation between the two Koreas is established, the hinterland located near the ports of North Korea is developed, and the vessels navigate between the two Koreas again. This study considers the characteristics of the North Korean ports and the hinterland located on the West Coast, as well as the characteristics of the ships that had been operated.

The assumptions shown in Table 4 are set considering the demands based on some minerals and rear sites, mainly on the three ports on the West Coast within the North territory, as well as the development direction of the West Coast port area in North Korea. The North Korean ports (Haeju Port, Nampo Port) handling underground resources reflected an increase of 10\% in the existing data for bulk carriers and general cargo ships, and ships carrying sand (by barge and sand carrier) were excluded from this simulation. This is because this study already knows about the main route of sand cargo (Haeju-Incheon), and by excluding the sand that accounts for a large proportion, the result can better extract the distribution of the operation of other ships focusing on the ports located on the West Coast of North Korea. Considering these conditions, the types of vessels and the number of operations to be newly navigated to the North Korean ports were estimated and reflected in the BN model.

The BN was constructed excluding gross tonnage and year (Figure 5). Based on the analysis of the distribution of interKorean navigation vessels, new assumptions (portions that take into account the products produced at the North Korean ports and items to be transported between the North and South Korea ports) are extracted and reflected in a simulation model.

Figure 6 presents the distribution of vessels between Nampo Port and ports in South Korea, assuming that inter-Korean economic cooperation and maritime transport is reactivated. Nampo Port is the largest container facilities in North Korea located on the West Coast, and not only container ships going to and from the North and South, but also the volume of transshipment containers that are imported and exported through Busan port are projected to increase. Thus, it is expected that Nampo Port

Table 4. Establishment of research assumptions according to the demands based on some minerals and rear sites and the development direction of the port area in the West Coast of North Korea

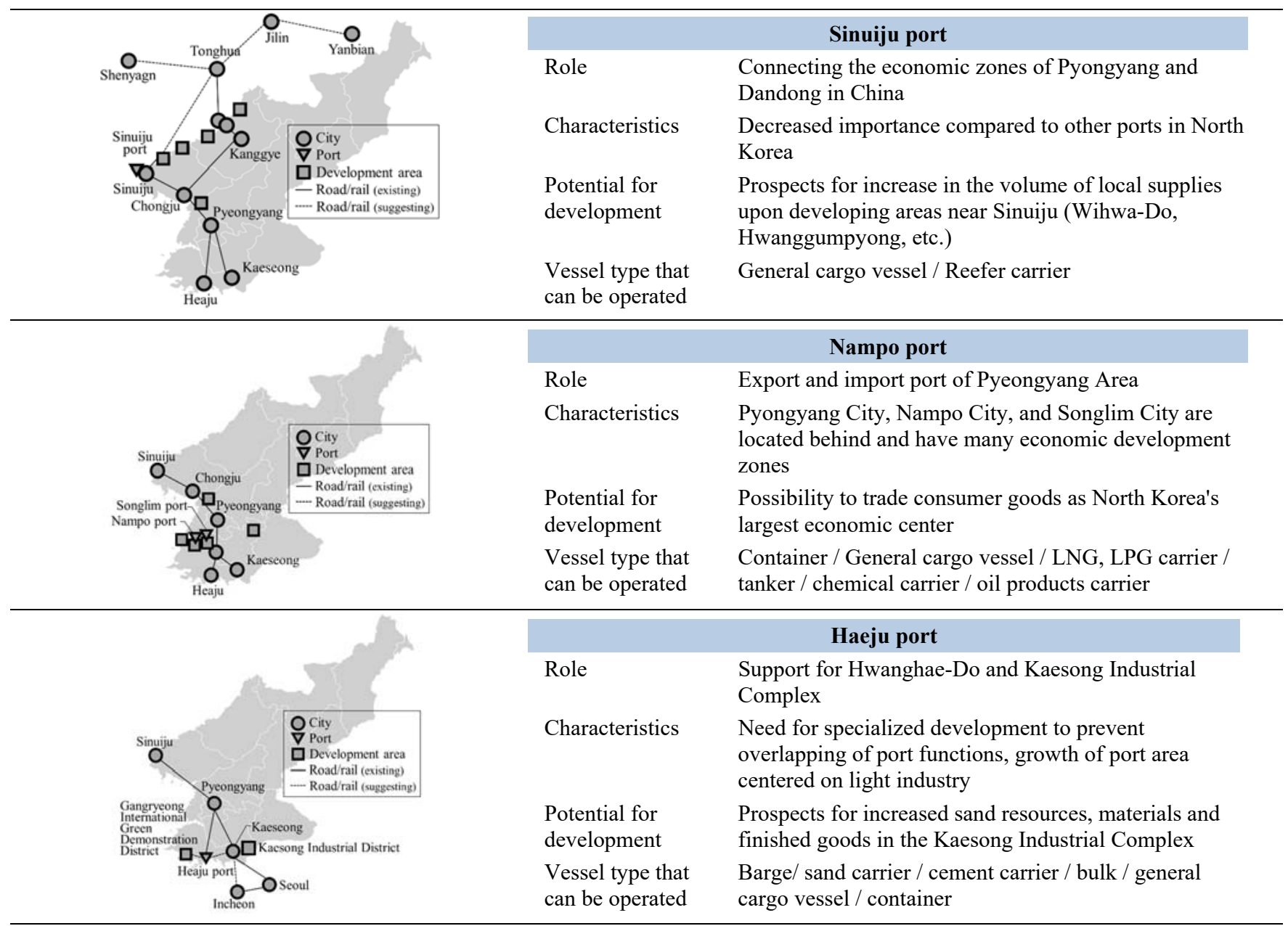

Source: Lee (2018), authors' elaboration. 


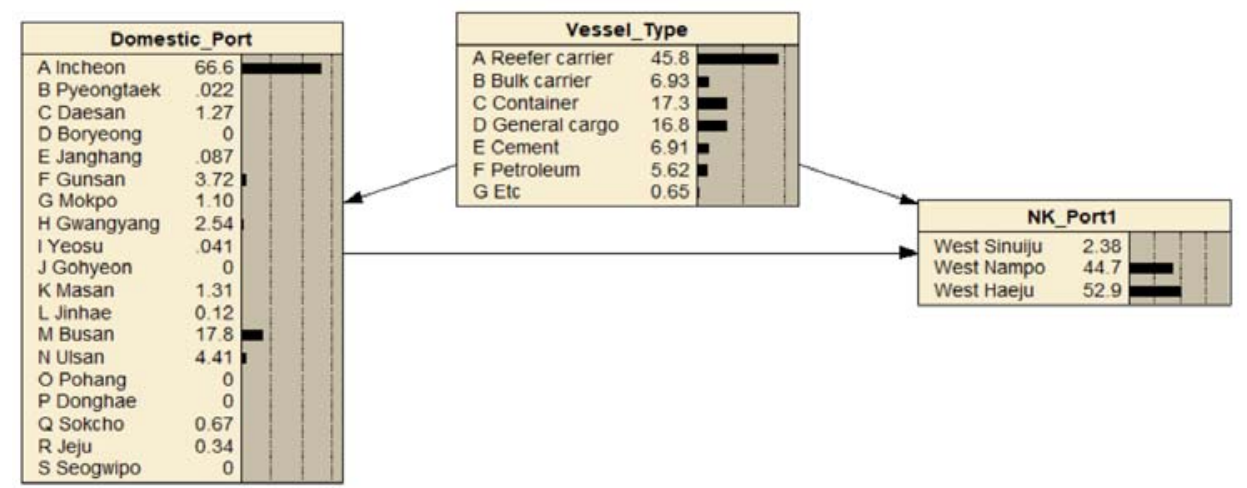

Figure 5. Bayesian Networks model after new data is updated.

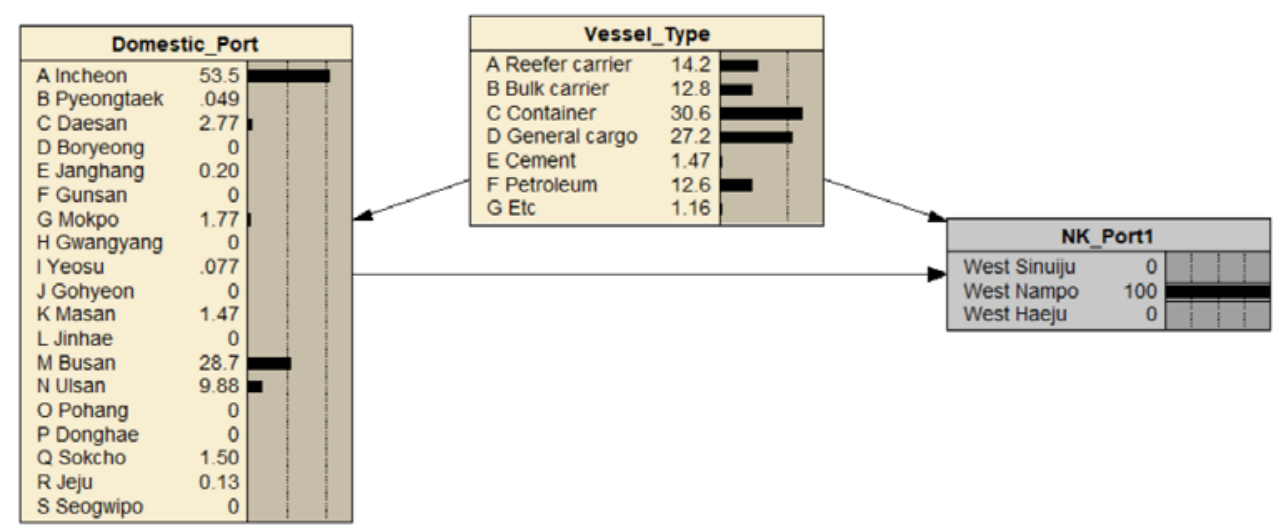

Figure 6. Distribution of vessel traffic between Nampo Port and South Korean ports by vessel (simulation case 1).

will serve as a feeder port.

In the case of Haeju Port, excluding sand transport, the traffic distribution of reefer carriers between the two Koreas is high as shown in Figure 7. This is due to the high distribution of reefer carriers, apart from ships that transport sand (barge, sand carriers). Also, it was assumed that cement carriers would be transported to North Korea since the demand for cement is bound to increase significantly if North Korea invests in infrastructure. Additionally, in view of the reserves of limestone concentrated in Pyongyang and Hwanghae Province, limestone was also considered to be brought into Korea from North Korea.

Figure 8 shows the distribution of container ships to and from North and South Koreas, assuming that maritime cargo is activated due to economic cooperation between South Korea and North Korea. In North Korea, the distribution of container ships to Nampo Port is expected to be the largest, and in Korea, the distribution to Incheon and Busan Ports is large. Nampo

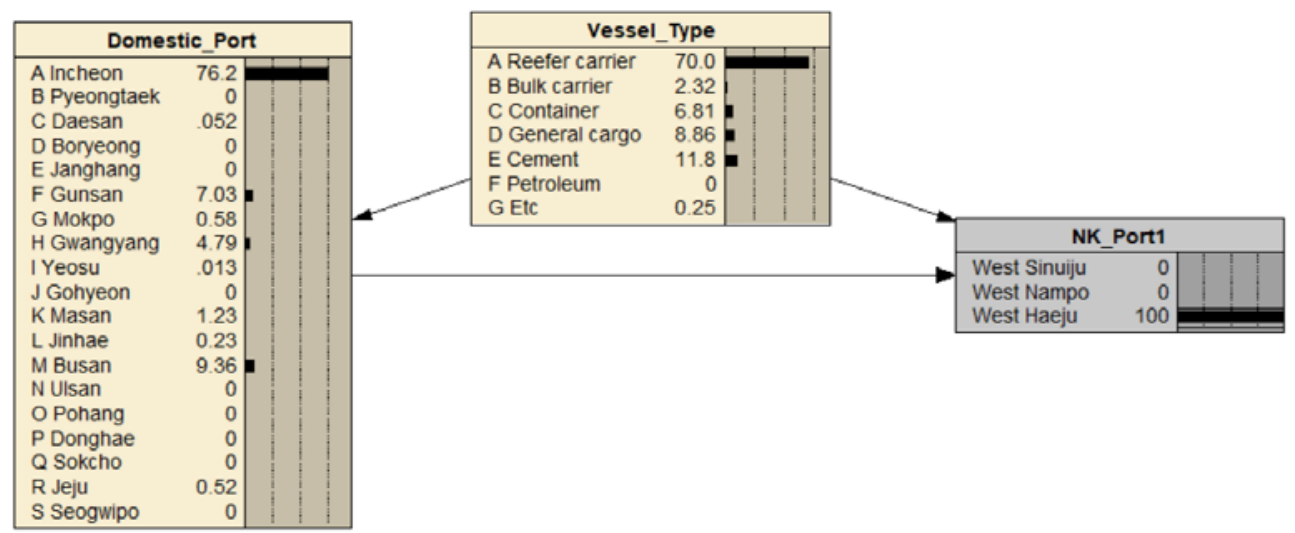

Figure 7. Distribution of vessel traffic between Haeju Port and South Korean ports by vessel (simulation case 2). 


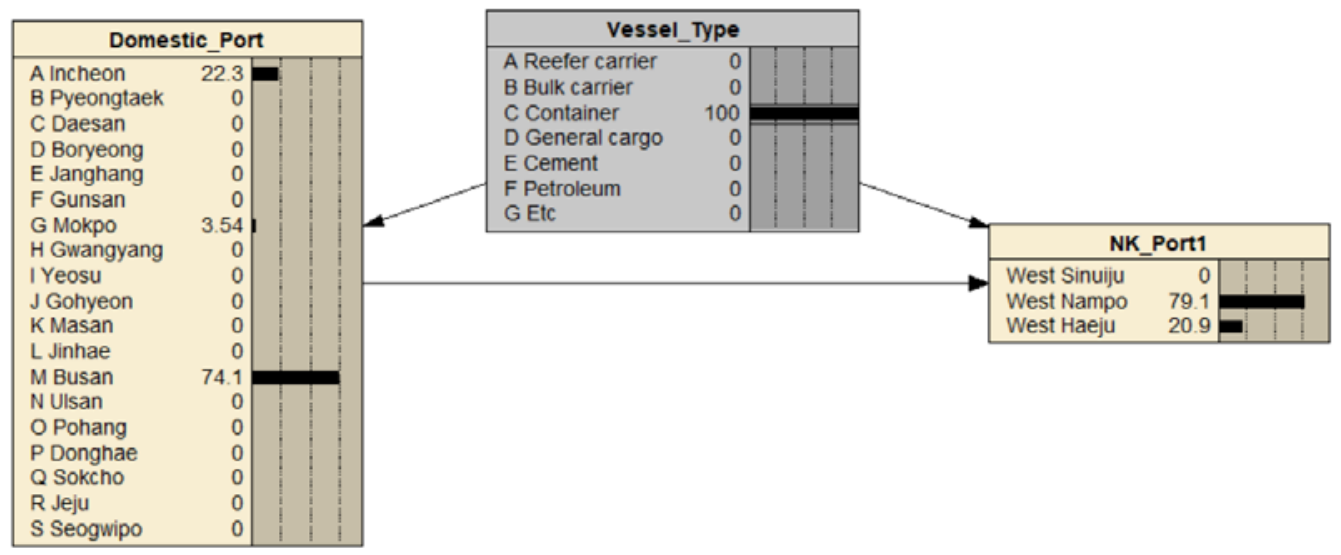

Figure 8. Distribution of container vessel traffic between the two Koreas (simulation case 3).

Port and Haeju Port, which are responsible for import/export of container cargo from all over the world as well as inter-Korean trade, will be the main ports of North Korea. Further, the Busan Port will become the Hub port, and container imports and exports to Nampo Port and Haeju Port will be made in transshipment container cargo form through coastal transportation and feeder.

\section{Concluding Remarks}

Coastal shipping between South and North Koreas plays a vital role in promoting economic cooperation between the two governments. Through this economic cooperation, the increase in trade volume between the two Koreas will lead to the development of domestic coastal transportation and eventually construct a virtuous cycle structure. Therefore, preparations and cooperation for coastal shipping between South and North Koreas need to be analyzed from a variety of perspectives in case trade between the two governments increases in the future based on improved inter-Korean relations.

This study was conducted for the purpose of examining and estimating vessel traffic between North and South Korean ports by vessel type. To do this, previous studies were analyzed, and the status and patterns of maritime transport between the two Koreas were analyzed through quantitative analysis. Prior studies conducted in-depth analyses of projects and policies that should be carried out in the shipping/port sector to prepare for the Unified Korean Peninsula Era. Due to the limitations in availability of data on maritime transport between the two Koreas, it was found that the studies related to maritime shipping/port focused on qualitative analysis in the past. Therefore, this study quantitatively approached the considerations regarding shipping/ports cooperation between two Koreas.

Port-MIS data was collected to visualize the traffic of inter-Korean ports, and the flow patterns of inter-Korean coastal ships and cargo were identified. Then, the BN method was used to analyze information on maritime transport between the North and South sides with a probability distribution for each route/vessel type. Based on these results, this study also conducted an estimate for maritime transport patterns of inter-Korean trade in the future.

The results of the analysis are as follows. First, when North-South routes are reopened, the volume of import for sand from North Korea will increase. Therefore, related issues must be resolved in advance to increase the efficiency of transportation of sand cargoes especially between the ports of Incheon and Heaju. Second, cargo vessels that had navigated inter-Korean waters represent the characteristics of 'simple piston-type' service, which leads to difficulties for sequential port calling. This type of service causes high transport cost for shipping companies operating in the North and South. Therefore, investments for the modernization of North Korean ports are required so that shipping companies can generate profit through economies of scale. Third, the number of vessels including container ships operating between the two governments is expected to increase in the case of strengthened economic cooperation, especially between Busan Port in South Korea and Nampo Port in North Korea. Lastly, for container ships, transshipment containers imported and exported through Busan Port will be shipped to North Korea with feeder transportation. This is expected to lead to the activation of coastal shipping in Korea.

If inter-Korean relations are improved by easing and releasing sanctions against North Korea, the Kaesong Industrial Complex on the West Coast will be restarted. This will lead to the development of the second Kaesong Industrial Complex as well as activation of export development zones around Nampo Port and Pyongyang. In South Korea, large quantities of raw materials and necessities for North Korea will be loaded on North Korean coastal ships that depart from Incheon and Busan 
ports. On the other hand, most of the products made in North Korea will be loaded on coastal cargo ships and depart from Nampo and Haeju ports. Based on accumulation of future vessel traffic data, this model can be updated and the probability distribution will also be updated. Utilizing this updated data, it will be possible to look at changes in all relevant variables. Also, based on this research, it will be possible to study the importance of the inter-Korean port networks in the future, analyzing factors such as inter-Korean container feeder service, linkage by products, and linkage between ports and land transportation.

When developing dedicated ports in the future, it is important to refer to the transport status by product/characteristic of hinterland. In this aspect, this study contributes to literature in that the data and methodology can provide the basic framework for future research on integrated logistics and multimodal transportation in the Korean Peninsula by presenting data-based maritime transport status and probability distribution.

The limitation of this study is that the estimation for the volume of North Korea's hinterland does not depend on scientific inference but rather the researcher's subjective understanding. However, this study is significant in that it provides a framework for analyzing the situation of maritime transport between the North and the South sides. Also, this study did not analyze the Songlim Port, which is one of the western ports in North Korea, due to the lack of shipping data for Songlim Port. Further research is needed to consider the Songlim Port and other Eastern ports in North Korea.

In the future, if the two Koreas set out on a path of cooperation, it will be possible not only to promote the creation of new jobs in industries related to shipping/ports but also to improve the inter-Korean logistics structure. Shipping/ports will be become a strong industry that supports balanced development of logistics-oriented countries in Northeast Asia. Continued studies on inter-Korean coastal shipping through various perspectives and analyzes will contribute to reducing the trial-anderror approach regarding inter-Korean sea transportation in advance in the era of peace on the Korean Peninsula.

\section{Acknowledgements}

This work was supported by Jungseok Logistics Foundation Grant.

\section{References}

Abdul Rahman, N. S. F., Yang, Z., Bonsall, S., Wang, J., 2015. A fuzzy rule-based Bayesian reasoning method for analysing the necessity of super slow steaming under uncertainty: Containership. International Journal of e-Navigation and Maritime Economy 3, 1-12.

Akhtar, M., Utne, I. B., 2014. Human fatigue's effect on the risk of maritime groundings: A Bayesian network modeling approach. Safety Science 62, 427-440.

Alyami, H., Lee, P. T. W., Yang, Z., Riahi R., Bonsall, S., Wang J., 2014. An advanced risk analysis approach for container port safety evaluation. Maritime Policy and Management 41, 634-650.

Baksh, A. A., Abbassi, R., Garaniya, V., Khan, F., 2018. Marine transportation risk assessment using Bayesian network: Application to Arctic waters. Ocean Engineering 159, 422-436.

Ducruet, C., 2008. Hub dependence in constrained economies: The case of North Korea. Maritime Policy \& Management 35, 377-394.

Ducruet, C., Roussin, S., Jo, J. C., 2009. Going west? Spatial polarization of the North Korean port system. Journal of Transport Geography 17, 357-368.

Hwang, J. H., Chun, W. H., 2018. Establishment of Maritime Cooperation in Accordance with Development of Inter-Korean Relations. Korea Maritime Institute, Seoul, Koea.

Im, J. G., 1995. Issues and future directions of inter-Korean Shipping Cooperation. Ocean \& Fisheries 131, 18-36.

Jiang, M., Lu, J., Yang, Z., Li, J., 2020. Risk analysis of maritime accidents along the main route of the maritime silk road: A Bayesian network approach. Maritime Policy \& Management, 1-18.

John, A., Yang, Z., Riahi, R., Wang, J., 2016. A risk assessment approach to improve the resilience of a seaport system using Bayesian networks. Ocean Engineering 111, 136-147.

Jung, B. M., 2008. Directions for the development of inter-Korean shipping. Ocean \& Fisheries 286, 12-25.

Kim, B. J., 2002. North Korean port development and inter-Korean port exchange cooperation plan. Ocean \& Fisheries 219, 19-39.

Kim, G. S., 1994a. Strengthening coastal shipping for Inter-Korean Shipping Cooperation (I). Monthly Maritime Korea 6, 3943. 
Kim, G. S., 1994b. Strengthening coastal shipping for Inter-Korean Shipping Cooperation (II). Monthly Maritime Korea 7, 4551.

Kim, Y. Y., 1998. Current Status of the shipping industry in North Korea and Inter-Korean Cooperation in the Shipping Sector. Korea Institute for National Unification, Seoul, Korea.

Kim, Y. Y., 2011. Current status and tasks of North Korea's shipping industry. Stratege 2114, 96-125.

Koo, M. G., 2019. Inter-Korean maritime cooperation under the peace regime on the Korean peninsula : Joint development of fisheries shipping and offshore oil fields. International Development and Cooperation Review 11, 1-16.

Lee, K. Y., Kim, G. S., Kim, B. K., Kong, Y. D., 2018. A Study on Cooperation Projects in Port \& Logistics Sector for the Improvement of Inter-Korean Relations. Korea Maritime Institute, Seoul, Korea.

Lee, S. W., 2018., Direction of North Korean port development for logistics integration and expansion on the Korean Peninsula. KDI Review of the North Korean Economy 20, 23-41.

Nadkarni, S., Shenoy, P. P., 2001. Bayesian network approach to making inferences in causal maps. European Journal of Operational Research 128, 479-498.

Park, H. G., Park, D. H., 2019. Evaluation of port choice factors in the west coast bay of North Korea. Journal of Shipping and Logistics 35, 407-428.

Park, S. J., Lee, S. W., 2017. Inter-Korean Maritime and Fishery Relation 1945-2015. Korea Maritime Institute, Seoul, Korea.

Rahman, A., Yang, Z. L., Bonsall, S., Wang, J., 2012. A proposed rule-based Bayesian reasoning appoarch for analysing steaming modes on containerships. Journal of Maritime Research 9, 27-32.

Salleh, N. H. M., Riahi, R., Yang, Z., Wang, J., 2014. A fuzzy Bayesian belief network approach for assessing the operational reliability of a liner shipping operator. Proceedings of the Second International Conference on Advances in Economics, Management and Social Study, New York, NY.

Salleh, N. H. M., Riahi, R., Yang, Z., Wang, J., 2017. Predicting a containership's arrival punctuality in liner operations by using a Fuzzy Rule-Based Bayesian Network (FRBBN). Asian Journal of Shipping and Logistics 33, 95-104.

Seo, D. W., Ko, J. O., Lee, S. H., 2012. Recent development in technologies for short sea shipping and its implications. Journal of Navigation and Port Research 36, 883-888.

Statistics Korea, 2020. Inter-Korean maritime transport volume. Available at: http://www.index.go.kr/potal/stts/idxMain/ selectPoSttsIdxSearch.do?idx_cd=1269 (Accessed 31 April 2020)

Shin, S. H., Lee, P.T.W., Lee, S. W., 2019. Lessons from bankruptcy of Hanjin Shipping Company in chartering. Maritime Policy and Management 46, 136-155.

Trucco, P., Cagno, E., Ruggeri, F., Grande, O., 2008. A Bayesian belief network modelling of organisational factors in risk analysis: A case study in maritime transportation. Reliability Engineering and System Safety 93, 845-856.

Wan, C., Yan, X., Zhang, D., Qu, Z., Yang, Z., 2019. An advanced fuzzy Bayesian-based FMEA approach for assessing maritime supply chain risks. Transportation Research Part E: Logistics and Transportation Review 125, 222-240.

Wang, G. W. Y., Yang, Z., Zhang, D., Huang, A., Yang, Z., 2017. Application of Bayesian networks in analysing tanker shipping bankruptcy risks. Maritime Business Review 2, 177-198.

Wang, L., Yang, Z., 2018. Bayesian network modelling and analysis of accident severity in waterborne transportation: A case study in China. Reliability Engineering and System Safety 180, 277-289.

Yang, Z., Abujaafar, K.M., Qu, Z., Wang, J., Nazir, S., Wan, C., 2019. Use of evidential reasoning for eliciting Bayesian subjective probabilities in human reliability analysis: A maritime case. Ocean Engineering 186, 106095.

Yang, Z., Yang, Z., Yin, J., 2018a. Realising advanced risk-based port state control inspection using data-driven Bayesian networks. Transportation Research Part A: Policy and Practice 110, 38-56.

Yang, Z., Yang, Z., Yin, J., Qu, Z., 2018b. A risk-based game model for rational inspections in port state control. Transportation Research Part E: Logistics and Transportation Review 118, 477-495.

Zhang, D., Yan, X. P., Yang, Z. L., Wall, A., Wang, J., 2013. Incorporation of formal safety assessment and Bayesian network in navigational risk estimation of the Yangtze river. Reliability Engineering and System Safety 118, 93-105. 